\title{
Wojciech Fill
}

Katedra Prawa Publicznego

Uniwersytet Ekonomiczny w Krakowie

\section{Prawnofinansowe konsekwencje wprowadzenia stanu nadzwyczajnego}

\section{Streszczenie}

Ustawy regulujące zasady funkcjonowania państwa w czasie obowiązywania stanów nadzwyczajnych nie zawierają norm prawnofinansowych. Konstytucyjna zasada wyjątkowości stanów nadzwyczajnych pozwala natomiast sądzić, że nadzwyczajność sytuacji, w jakiej znalazło się państwo i jego obywatele podczas stanu nadzwyczajnego, uzasadnia podejmowanie decyzji finansowych prawnie niedopuszczalnych w innych okolicznościach. Tezę tę zdaje się potwierdzać również ustawa o finansach publicznych, przewidująca wyłączenie na czas trwania stanu nadzwyczajnego obowiązywania niektórych regulacji dotyczących m.in. rygorów związanych z tzw. wydatkową regułą dyscyplinującą, podziałem rezerw celowych i rezerwy ogólnej oraz dokonywaniem przeniesień wydatków budżetowych, a nade wszystko - ograniczeń związanych z wprowadzeniem procedur ostrożnościowych i sanacyjnych. Pojawia się zatem pytanie, jak daleko w sferze regulacji prawa finansowego może posunąć się obdarzona szczególnymi kompetencjami w okresie stanu nadzwyczajnego władza wykonawcza, aby nie doprowadzić do utraty statusu demokratycznego państwa prawnego.

Słowa kluczowe: stan nadzwyczajny, procedura sanacyjna, wydatkowa reguła dyscyplinująca, rezerwy budżetowe, przeniesienia wydatków, rygory fiskalne, procedura nadmiernego deficytu. 


\section{Wprowadzenie}

Zarówno Konstytucja, jak i ustawy szczegółowe normujące zasady funkcjonowania państwa w sytuacji wprowadzenia stanu wojennego, stanu wyjątkowego oraz stanu klęski żywiołowej ${ }^{1}$ nie określają bezpośrednio reguł dotyczących finansowania działań związanych z realizacją celów wskazanych w tych ustawach. W aktach tych ustawodawca kładzie wyraźny akcent na pozafinansowe regulacje dotyczące trybu i celu wprowadzenia stanu nadzwyczajnego, przesłanek jego zastosowania, zakresu terytorialnego oraz czasu obowiązywania [Mażewski 2009, s. 26]. Jednocześnie wynikająca wprost z art. 228 Konstytucji zasada wyjątkowości stanów nadzwyczajnych [Prokop 2005, s. 17 i nast.], zgodnie z którą stany te mogą być wprowadzone tylko w warunkach szczególnych zagrożeń, gdy zwykłe środki konstytucyjne nie są wystarczające, pozwala sądzić, że wyjątkowość sytuacji, w jakiej znalazło się państwo i jego obywatele, uzasadnia podejmowanie decyzji finansowych prawnie niedopuszczalnych w innych okolicznościach. Tezę tę zdaje się potwierdzać również Ustawa z dnia 27 sierpnia 2009 r. o finansach publicznych ([Ustawa z dnia 27 sierpnia 2009 r. ...], dalej: u.f.p.), przewidująca wyłączenie w czasie stanu nadzwyczajnego obowiązywania niektórych regulacji dotyczących m.in. rygorów związanych z tzw. wydatkową regułą dyscyplinującą, podziałem rezerw celowych i rezerwy ogólnej oraz z dokonywaniem przeniesień wydatków budżetowych, a nade wszystko ograniczeń związanych z wprowadzeniem procedur ostrożnościowych i sanacyjnych [Lipiec-Warzecha 2011, s. 463]. $\mathrm{Z}$ uwagi na brak w ustawie o finansach publicznych innych regulacji dotyczących prowadzenia publicznej gospodarki finansowej w okresie stanu nadzwyczajnego - przy jednoczesnym braku konstytucyjnego zakazu normatywnej ingerencji w regulacje prawa finansowego - ustawodawca jest związany niezmienialnymi w okresie stanu nadzwyczajnego regułami konstytucyjnymi (art. 228 ust. 6 Konstytucji) dotyczącymi m.in.: formy prawnej nakładania podatków i innych opłat publicznych, wysokości państwowego długu publicznego, procedury budżetowej, zakazu pokrywania deficytu budżetowego przez zaciąganie zobowiązań w centralnym banku państwa, a także unormowaniami dotyczącymi funkcji i źródeł finansowania jednostek samorządu terytorialnego. Poza sferą bezpośredniej regulacji konstytucyjnej pozostaje m.in. gospodarka państwowych i samorządowych jednostek organizacyjnych oraz funduszy celowych. W okresie stanu nadzwyczajnego ustawodawca może zatem dokonywać przekształceń w zakresie

\footnotetext{
${ }^{1}$ Odpowiednio: Ustawa z dnia 29 sierpnia 2002 r. o stanie wojennym oraz o kompetencjach Naczelnego Dowódcy Sił Zbrojnych i zasadach jego podległości konstytucyjnym organom Rzeczypospolitej Polskiej [Ustawa z dnia 29 sierpnia 2002 r. ...], Ustawa z dnia 21 czerwca 2002 r. o stanie wyjątkowym [Ustawa z dnia 21 czerwca 2002 r. ...], Ustawa z dnia 18 kwietnia 2002 r. o stanie klęski żywiołowej [Ustawa z dnia 18 kwietnia 2002 r. ...].
} 
funkcjonowania tych jednostek sektora finansów publicznych, będąc związanym w zasadzie tylko regułą demokratycznego państwa prawnego oraz ,istotą” określonych w Konstytucji praw obywatelskich (art. 31 ust. 3 in fine Konstytucji). Obie kategorie ograniczeń są niejednoznaczne pod względem zakresu desygnatów i w praktyce ich zastosowanie prawie zawsze wymaga złożonej egzegezy (por. [Banaszak 2012, s. 17-56]). Pojawia się zatem pytanie, jak daleko w sferze regulacji prawa finansowego może posunąć się obdarzona szczególnymi kompetencjami w okresie stanu nadzwyczajnego władza wykonawcza, aby nie doprowadzić do utraty statusu demokratycznego państwa prawnego (por. [Bryk 2011, s. 224]).

\section{Zakres regulacji normatywnej}

Zgodnie z treścią art. 88 u.f.p. w przypadku wprowadzenia jednego ze stanów nadzwyczajnych ${ }^{2}$ nie stosuje się rozwiązań normatywnych zwanych procedurami ostrożnościowymi i programami sanacyjnymi (zob. art. 86-87 u.f.p.). Aby przedstawić konsekwencje zastosowania tej normy, warto odczytać treść procedur ostrożnościowych a contrario. Wykładnia taka pozwala na wniosek, że przekroczenie każdego z określonych w ustawie progów ostrożnościowych nie wymaga podejmowania żadnych działań związanych z ograniczaniem deficytu budżetowego, a w szczególności nie wymaga równoważenia ścisłego budżetu w celu ograniczenia wysokości długu publicznego. W sytuacji wprowadzenia stanu nadzwyczajnego pojawi się ponadto możliwość kształtowania wysokości planowanych na przyszły rok budżetowy pożyczek i kredytów z budżetu państwa oraz dowolność określania w projekcie przyszłorocznego budżetu wydatków jednostek organizacyjnych obsługujących naczelne organy władzy ustawodawczej, wykonawczej i sądowniczej (określonych w art. 139 ust. 2 u.f.p.). Rada Ministrów uzyska także możliwość dowolnego określenia w projekcie przyszłorocznej ustawy budżetowej poziomu wynagrodzeń pracowników państwowej sfery budżetowej oraz wysokości rent i emerytur. Rada Ministrów zostanie ponadto zwolniona z konieczności przedstawienia sejmowi programu sanacyjnego mającego na celu obniżenie wysokości współczynnika zadłużenia publicznego do produktu krajowego brutto oraz z wymogu dokonania przeglądu obowiązujących przepisów w celu przedstawienia propozycji rozwiązań prawnych mających wpływ na poziom dochodów budżetu państwa, w tym dotyczących stosowania stawek podatku od towarów i usług (art. 86 ust. 1 pkt 2 lit. e u.f.p. a contrario). Warto podkreślić, że przekroczenie limitów uzasadniających wprowadzenie procedur sanacyjnych nie

\footnotetext{
${ }^{2}$ Art. 88 u.f.p. nie stosuje się w przypadku wprowadzenia stanu nadzwyczajnego lub stanu klęski żywiołowej na części terytorium kraju. Wskazane wyłączenie obligatoryjnie obowiązuje jednak w przypadku objęcia części kraju stanem wojennym.
} 
będzie także skutkowało koniecznością ścisłego równoważenia budżetów lokalnych lub koniecznością stosowania w odniesieniu do tych budżetów sanacyjnej reguły wydatkowej. Korzystając z wykładni art. 86 a contrario, można również zauważyć, że wprowadzenie na terytorium kraju stanu nadzwyczajnego pozwoliłoby nawet na całkowite wyeliminowanie dotacji celowej z budżetu państwa, przeznaczanej na realizację przez Państwowy Fundusz Rehabilitacji Osób Niepełnosprawnych wypłaty miesięcznych dofinansowań dla pracodawców zatrudniających osoby niepełnosprawne ${ }^{3}$, zaś organy administracji rządowej mogłyby zaciągać nowe zobowiązania na przygotowanie inwestycji bez względu na rodzaj i wysokość źródeł ich finansowania.

Ważnym elementem charakterystyki wskazanych skutków wprowadzenia stanu nadzwyczajnego wydaje się też określenie czasu ich powstawania. W pierwszej kolejności należy jednak usystematyzować terminarz wprowadzania poszczególnych instrumentów w ramach procedur sanacyjnych. Relację państwowego długu publicznego do produktu krajowego brutto ogłasza się według stanu na koniec roku budżetowego, w terminie do 31 maja roku następnego. Procedury sanacyjne i programy ostrożnościowe mogą być realizowane dopiero po ogłoszeniu danych wskazujących na przekroczenie normatywnych limitów zadłużenia. Z uwagi na czynnik czasu w ramach rozwiązań ustawowych można wyodrębnić dwie grupy procedur sanacyjnych. Pierwszą grupę stanowią działania, których skutki finansowe znajdą odzwierciedlenie w ustawie budżetowej obowiązującej w roku przekroczenia dopuszczalnych limitów, drugą zaś grupę - czynności, których konsekwencje finansowe zaczną obowiązywać w kolejnym roku budżetowym. Do grupy pierwszej zaliczyć można m.in. zakaz udzielania nowych poręczeń i gwarancji przez jednostki sektora finansów publicznych ${ }^{4}$ oraz ograniczenie maksymalnej wysokości dotacji celowej z budżetu państwa dla Państwowego Funduszu Rehabilitacji Osób Niepełnosprawnych do 30\% kwoty planowanej ${ }^{5}$, a także uzależnienie możliwości zaciągania nowych zobowiązań na przygotowanie inwestycji przez organy administracji rządowej od zapewnienia minimalnie 50-procentowego pokrycia kosztów inwestycji z budżetu Unii Europejskiej lub innych źródeł zagranicznych ${ }^{6}$. W drugiej grupie mieszczą się działania planistyczne związane z wprowadzeniem ograniczeń do przyszłorocznego budżetu

\footnotetext{
${ }^{3}$ Zob. art. 26a Ustawy z dnia 27 sierpnia 1997 r. o rehabilitacji zawodowej i społecznej oraz zatrudnianiu osób niepełnosprawnych [Ustawa z dnia 27 sierpnia 1997 r. ...].

${ }^{4}$ Ograniczenie to dotyczy tylko sytuacji, w której wartość relacji między państwowym długiem publicznym a produktem krajowym brutto jest równa lub większa od $60 \%$.

${ }^{5}$ Ograniczenie to dotyczy tylko sytuacji, w której wartość relacji między państwowym długiem publicznym a produktem krajowym brutto jest większa od 50\%, a mniejsza od 55\%.

${ }^{6}$ Procedura ta dotyczy dwóch najwyższych progów ostrożnościowych wskazanych w poprzednich przypisach.
} 
państwa oraz budżetów lokalnych. Warto zaznaczyć, że w zasadzie jedynym działaniem prawnym, którego termin podjęcia w ramach procedur sanacyjnych został wyznaczony w sposób bezwzględnie obowiązujący, jest zakaz udzielania przez jednostki sektora finansów publicznych nowych poręczeń i gwarancji - począwszy od siódmego dnia od momentu obwieszczenia o przekroczeniu trzeciego progu ostrożnościowego (art. 86 ust.1 pkt 3 lit. d u.f.p.).

We wszystkich pozostałych przypadkach termin podjęcia konkretnych czynności ma charakter uznaniowy. Oznacza to, że poza czynnościami, których tok jest wymuszony ustawowymi terminami realizacji poszczególnych etapów procedury budżetowej, podjęcie działań polegających na dokonywaniu stosownych analiz, a także zakazie zaciągania niektórych zobowiązań inwestycyjnych przez organy administracji rządowej i ograniczaniu dotacji, powinno nastąpić w terminie do końca roku, w którym nastąpiło ogłoszenie przekroczenia progu ostrożnościowego. Wątpliwości dotyczące określenia konkretnego momentu podjęcia działań sanacyjnych, wynikające z zastosowania wykładni językowej, przynajmniej częściowo można rozproszyć, odwołując się do dyrektyw wykładni systemowej oraz funkcjonalnej. Zarówno bowiem wyodrębnienie w ustawie o finansach publicznych jednostki redakcyjnej zatytułowanej „Procedury ostrożnościowe i sanacyjne", jak i sam cel analizowanej grupy regulacji zdają się wskazywać na wymóg niezwłocznego podjęcia działań „uzdrawiających” jako zasadniczą regułę interpretacyjną. Jak powszechnie wiadomo, niezwłoczność nie zawsze musi oznaczać natychmiastowość. Stąd, kierując się wskazaną regułą interpretacyjną, można uznać, że czynności składające się na procedury sanacyjne powinny być podejmowane z uwzględnieniem czasu potrzebnego na dokonanie pogłębionej refleksji nad kierunkiem zachodzących procesów finansowo-gospodarczych.

Charakter niezwłoczny powinno mieć w szczególności działanie polegające na dokonaniu przeglądu wydatków budżetu państwa finansowanych środkami pochodzącymi z kredytów zagranicznych oraz dokonaniu przeglądu obowiązujących przepisów w celu przedstawienia propozycji rozwiązań prawnych mających wpływ na poziom dochodów budżetu państwa, w tym dotyczących stosowania stawek podatku od towarów i usług. Jak można sądzić, konsekwencje tych przeglądów znajdą swój zasadniczy, ekonomiczny wyraz dopiero w sporządzanym przez Radę Ministrów programie sanacyjnym, mającym na celu obniżenie relacji przekraczającej dany próg ostrożnościowy. Dokumenty, które powstaną w wyniku dokonania wymaganych ustawą przeglądów, będą stanowiły również istotny element oceny makroekonomicznych uwarunkowań planowania budżetu na rok następny. Tezy tam zawarte zapewne w znaczącej części zostaną włączone do uzasadnienia projektu ,sanacyjnej” ustawy budżetowej. 


\section{Temporalne elementy wykładni}

Poza kwestiami czasowymi wdrażania prawnofinansowych instrumentów w ramach procedur sanacyjnych ciekawie przedstawia się zagadnienie maksymalnego okresu obowiązywania poszczególnych stanów nadzwyczajnych i wynikające stąd możliwości prawnego i faktycznego niezastosowania dyspozycji przepisów regulujących procedury sanacyjne. Stan klęski żywiołowej może obowiązywać przez czas oznaczony nie dłuższy niż 30 dni, przy czym za zgodą sejmu okres ten może zostać przedłużony w dowolnym zakresie. Stan wyjątkowy z kolei może zostać wprowadzony na czas oznaczony nie dłuższy niż 90 dni, zaś jego przedłużenie może nastąpić tylko raz, na czas nie dłuższy niż 60 dni. Konstytucja nie określa natomiast ram czasowych obowiązywania stanu wojennego. Jedynie w przypadku wprowadzenia stanu wyjątkowego można zatem z góry przyjąć, że okres jego obowiązywania nie będzie dłuższy niż 150 dni. Wobec powyższego, tworząc teoretyczny model zależności czasowych między obowiązywaniem stanu nadzwyczajnego a pojawieniem się wyznaczonej normatywnie konieczności podjęcia procedur sanacyjnych, można przyjąć, że stan nadzwyczajny zostanie wprowadzony przed dniem ogłoszenia relacji powodującej konieczność podjęcia procedur sanacyjnych. Wówczas obowiązek podejmowania działań w ramach tych procedur nie powstanie aż do czasu zakończenia stanu nadzwyczajnego. W przypadku obowiązywania stanu nadzwyczajnego - w szczególności stanu wojennego - przez okres dłuższy niż do końca roku budżetowego, skutki prawne przekroczenia progu ostrożnościowego utracą znaczenie prawne. Stanie się tak w związku z niemożnością podjęcia ani określonych w ustawie działań sanacyjnych o charakterze doraźnym, ani działań związanych z planowaniem budżetowym. Jeżeli z kolei stan nadzwyczajny zostanie uchylony przed końcem roku, w którym przekroczono próg ostrożnościowy, należy podjąć te procedury sanacyjne, które zgodnie z ustawą o finansach publicznych są możliwe w tym czasie do wykonania.

Podstawowa procedura sanacyjna dotyczy ograniczeń wydatków budżetowych na przyszły rok. Może się zatem okazać, że stan nadzwyczajny zostanie uchylony po przedłożeniu sejmowi projektu przyszłorocznego budżetu - niezawierającego żadnych ograniczeń wydatkowych wynikających z właściwej procedury sanacyjnej - lub nawet po uchwaleniu takiego budżetu przez sejm. Wówczas uchylenie stanu nadzwyczajnego będzie się wiązało z normatywnym wymogiem dokonania przez Radę Ministrów przeglądu wydatków budżetowych, ograniczeniem możliwości zaciągania nowych zobowiązań na przygotowanie inwestycji przez organy administracji publicznej oraz możliwością obniżenia dotacji celowej dla Państwowego Funduszu Rehabilitacji Osób Niepełnosprawnych. Z badanych przepisów nie wynika natomiast konieczność wprowadzenia do uchwalonego już budżetu zmian 
zgodnych z procedurą sanacyjną. Ponadto w przypadku przekroczenia trzeciego progu ostrożnościowego, prima facie z wykładni językowej, sprzeczna z prawem wydaje się możliwość związania Rady Ministrów obowiązkiem przedstawienia sejmowi programu sanacyjnego mającego na celu ograniczenie relacji między państwowym długiem publicznym a produktem krajowym brutto do $60 \%{ }^{7}$. $\mathrm{Z}$ uwagi na upływ w trakcie obowiązywania stanu nadzwyczajnego określonego w analizowanych przepisach terminu można uznać za niewykonalną również ustawową dyspozycję dotyczącą zakazu udzielania przez jednostki sektora finansów publicznych nowych poręczeń i gwarancji (zob. art. 86 ust. 1 pkt 3 lit. d u.f.p.).

$\mathrm{Z}$ drugiej jednak strony, o ile stan nadzwyczajny zostałby zniesiony w roku przekroczenia progu ostrożnościowego, kierując się wykładnią funkcjonalną, można by też wywodzić, że na skutek wprowadzenia stanu nadzwyczajnego doszło do wstrzymania lub zawieszenia biegu terminu wprowadzenia wskazanych rozwiązań sanacyjnych. Pomimo więc posłużenia się przez ustawodawcę w treści art. 86 ust.1 pkt 3 lit. b u.f.p. sformułowaniem „,najpóźniej w terminie miesiąca od dnia ogłoszenia relacji”, nie można bezrefleksyjnie przyjąć, iż termin ten ma charakter zawity. Jeszcze większe wątpliwości w tym zakresie budzi sformułowanie zawarte $\mathrm{w}$ art. 86 ust. 1 pkt 3 lit. d u.f.p.: ,[...] poczynając od siódmego dnia po dniu ogłoszenia relacji, [...] jednostki sektora finansów publicznych nie mogą udzielać nowych poręczeń i gwarancji”. Z przepisu tego wprost wynika bowiem możliwość zastosowania normy ze skutkiem ex nunc. Jeżeli jednak w odniesieniu do wskazanych przepisów zostałaby zastosowana wykładnia pozbawiająca je mocy wiążącej, wówczas również w kolejnym roku zostanie naruszony próg ostrożnościowy, co wymusi podjęcie jeszcze radykalniejszych cięć wydatków w projekcie kolejnego budżetu. Alternatywę może stanowić wówczas zawieszenie obowiązywania procedur ostrożnościowych i sanacyjnych w drodze nowelizacji ustawy, co pozwoliłoby na dalsze zwiększenie zadłużenia publicznego, jeżeli byłoby to konieczne ze względów polityczno-społeczno-gospodarczych.

Jeżeli stan nadzwyczajny zostanie wprowadzony po dniu ogłoszenia relacji powodującej wymóg uruchomienia procedur sanacyjnych, wówczas wydaje się zgodna z prawem możliwość dokonania - zarówno w projekcie budżetu, jak i w budżecie już uchwalonym - zmian powodujących zwiększenie wydatków ponad limity wynikające z zastosowania procedur sanacyjnych. Rozwiązanie takie wydaje się również zdroworozsądkowe wobec nagłej konieczności intensyfikacji wydatków publicznych w celu zapobieżenia zagrożeniom, które spowodowały wprowadzenie stanu nadzwyczajnego.

\footnotetext{
${ }^{7}$ Zgodnie z art. 86 ust. 1 pkt 3 lit. b u.f.p. rada ministrów najpóźniej w terminie miesiąca od dnia ogłoszenia relacji między państwowym długiem publicznym a produktem krajowym brutto przedstawia sejmowi program sanacyjny mający na celu ograniczenie tej relacji do poziomu poniżej $60 \%$.
} 
Wobec wyjątkowości sytuacji związanej z wprowadzeniem stanu nadzwyczajnego w analizowanym kontekście rozważyć także można konsekwencje prawne mogące powstać w przypadku podjęcia prac nad projektem ustawy o prowizorium budżetowym oraz $\mathrm{w}$ wyniku przyjęcia przez sejm ustawy o prowizorium budżetowym. W treści przepisów ustawy o finansach publicznych brakuje regulujących procedury ostrożnościowe i sanacyjne odniesień do takiej sytuacji. Wobec tego zgodnie z wykładnią językową w przypadku prac nad projektem ustawy o prowizorium budżetowym nie istnieje obowiązek uwzględniania procedur sanacyjnych i ostrożnościowych bez względu na to, czy stan nadzwyczajny został wprowadzony przed dniem ogłoszenia przekroczenia progu ostrożnościowego, czy też po tym dniu. Wniosek ten można również uzasadnić tymczasowym charakterem zastosowana instytucji prowizorium budżetowego. Jeżeli natomiast zniesienie stanu nadzwyczajnego nastąpiłoby przed zakończeniem prac nad uchwaleniem projektu budżetu, należałoby w jego treści uwzględnić przewidziane prawem rygory sanacyjne. Oczywiście możliwa jest także i w tej sytuacji nowelizacja ustawy o finansach publicznych polegająca na zawieszeniu obowiązywania procedur sanacyjnych.

Barierę w swobodnym kształtowaniu przez Radę Ministrów wysokości długu publicznego oraz deficytu budżetowego w przypadku obligatoryjnego zawieszenia procedur sanacyjnych z uwagi na wprowadzenie jednego ze stanów nadzwyczajnych określa ponadto art. 216 ust. 5 Konstytucji stanowiący, iż nie wolno zaciągać pożyczek lub udzielać gwarancji i poręczeń finansowych, w następstwie których państwowy dług publiczny przekroczy $3 / 5$ wartości rocznego produktu krajowego brutto. Paradoksem jest, że o ile w okresie, w którym nie obowiązuje stan nadzwyczajny, konstytucyjne ograniczenie można zmienić - jeżeli będą za tym przemawiać względy ekonomiczne lub nawet jedynie polityczne - o tyle w stanie nagłej konieczności intensyfikacji wydatków publicznych z uwagi na wystąpienie rzeczywistego zagrożenia życia obywateli bądź nawet bytu prawnego państwa po wprowadzeniu jednego ze stanów nadzwyczajnych konstytucyjny limit zadłużenia publicznego nie może być ani zmieniony, ani przekroczony pod sankcją odpowiedzialności przed Trybunałem Stanu za naruszenie Konstytucji [Lipiec-Warzecha 2011, s. 457]. Poza sporem doktrynalnym jest racjonalność funkcjonowania w systemie prawa finansowego reguł służących ograniczaniu rozmiarów zadłużenia publicznego [Ustawa... 2012, s. 522; Kosikowski 2011, s. 254; Sobczyński 2003, s. 12]. Wpisane są one do Traktatu o funkcjonowaniu Unii Europejskiej, wiążąc tym samym wszystkie państwa członkowskie. Jednak w literaturze można odnaleźć również pogląd, że wprowadzenie do Konstytucji wymogu automatycznego i obligatoryjnego uruchamiania procedur sanacyjnych jest rozwiązaniem co najmniej niepraktycznym, mogącym pogarszać sytuację ekonomiczną i finansową państwa, zamiast służyć jej sanacji [Polarczyk 2005, 
s. 3-4]. Limity zadłużenia powinny bowiem służyć poprawie sytuacji ekonomiczno-gospodarczej, przede wszystkim poprzez zmuszenie organów władzy do dokonania realistycznej oceny sytuacji finansowej w celu podjęcia działań zaradczych, które mogą polegać zarówno na intensyfikacji wydatków publicznych (a tym samym najczęściej na zwiększeniu zadłużenia publicznego), jak i na ograniczeniach służących zmniejszeniu zadłużenia - w zależności od okoliczności, nie zaś jedynie na mechanicznym, każdorazowym ograniczeniu zadłużenia [Polarczyk 2005, s. 3-4; Kosikowski i Szpringer 2000, s. 137]. Ponadto jeżeli za grupę okoliczności pogarszających sytuację finansową państwa - w stopniu uzasadniającym zawieszenie niektórych procedur sanacyjnych - można uznać konsekwencje obecnego kryzysu gospodarczego w Polsce ${ }^{8}$, to tym bardziej za wyłączeniem obowiązywania limitów zadłużenia przemawia wystąpienie okoliczności uzasadniających wprowadzenie jednego ze stanów nadzwyczajnych, zawsze wiążących się z ogromnym obciążeniem finansowym państwa. Stąd wydaje się, iż w przepisach Konstytucji istnieje luka, która może wywołać paraliż decyzyjny w przypadku uwarunkowanej racją stanu konieczności przekroczenia wskazanego w Konstytucji limitu zadłużenia w okresie stanu nadzwyczajnego. Prorocza może się wówczas okazać konstatacja, że w istnienie państwa wpisane są takie sytuacje, w których niezbędne staje się podjęcie działań niemieszczących się w porządku prawnym [Zubik 2001, s. 303].

\section{Planowanie wieloletnie, wydatkowa reguła dyscyplinująca oraz rezerwy}

W przypadku wprowadzenia stanu nadzwyczajnego na terytorium całego kraju nie stosuje się również niektórych wymogów ustawy o finansach publicznych, stanowiących rozwinięcie konstytucyjnej reguły określania finansowych konsekwencji wprowadzenia danego aktu normatywnego do obrotu prawnego (art. 118 ust. 3 Konstytucji) [Lipiec-Warzecha 2011, s. 251]. Wyłączeniem tym objęte są normy wynikające z art. 50 ust. 1a-1c, 4, 5 i 7 u.f.p. Zgodnie z ich treścią każdy projekt przyjmowanej przez Radę Ministrów ustawy mogącej powodować zmianę poziomu wydatków jednostek sektora finansów publicznych w stosunku do wiel-

\footnotetext{
${ }^{8} \mathrm{Na}$ mocy Ustawy z dnia 26 lipca 2013 r. o zmianie ustawy o finansach publicznych w okresie od 1 stycznia do 31 grudnia 2013 r. zawieszono m.in. obowiązywanie art. 86 ust. 1 pkt 1 u.f.p. Nowelizacja ta umożliwia ukształtowanie się zależności między państwowym długiem publicznym a produktem krajowym brutto na poziomie przekraczającym 50\% w celu uniknięcia konieczności podjęcia restrykcyjnych działań ograniczających deficyt sektora finansów publicznych w momencie, kiedy gospodarka znajduje się w fazie spowolnienia (zob. uzasadnienie projektu ustawy).
} 
kości wynikających z obowiązujących przepisów należy określić bezpośrednio w treści projektu, wskazując maksymalny, kwotowy limit tych wydatków na okres 10 lat budżetowych, oddzielnie dla każdego roku, poczynając od pierwszego roku planowanego wejścia w życie ustawy, w podziale na budżet państwa, budżety jednostek samorządu terytorialnego oraz pozostałych jednostek sektora finansów publicznych. Ponadto Rada Ministrów ma obowiązek przedstawić sejmowi na 3 lata przed upływem ustawowego 10-letniego okresu projekt zmiany ustawy określającej maksymalne limity wydatków sektora finansów publicznych na kolejnych 10 lat budżetowych wykonywania ustawy. Projekt takiej ustawy powinien również określać mechanizmy korygujące, mające zastosowanie w przypadku przekroczenia lub zagrożenia przekroczenia przyjętego na dany rok budżetowy maksymalnego limitu wydatków. Wskazane mechanizmy korygujące mogą polegać na limitowaniu ilości udzielanych świadczeń w zależności od poziomu środków przeznaczonych na ten cel w ustawie lub na uzależnieniu wypłat od kryterium dochodowego, względnie majątkowego, uprawniającego do nabywania świadczeń finansowanych ze środków publicznych, albo też na ewentualnej zmianie kosztów realizacji zadań wykonywanych na rzecz obywateli ${ }^{9}$.

Unormowania art. 50 ust. 1a-1c, 4, 5 i 7 zostały włączone do ustawy o finansach publicznych w wyniku nowelizacji z dnia 16 grudnia $2010 \mathrm{r}$. [Ustawa z dnia 16 grudnia 2010 r. .... Sa one elementem szerszej regulacji art. 50, którego ratio legis ma służyć urealnieniu planowania wieloletniego [Kosikowski 2011, s. 182] poprzez, z jednej strony, stworzenie możliwości przypisania odpowiedzialności za wywołanie negatywnych skutków finansowych wprowadzoną do systemu prawnego ustawą (i tym samym uruchomienie mechanizmów samodyscyplinujących autorów projektów legislacyjnych), z drugiej zaś - zapewnienie sejmowi faktycznej możliwości zapoznania się ze skutkami wdrożenia projektów legislacyjnych [Ustawa... 2012, s. 390-391; Lipiec-Warzecha 2011, s. 252]. Normatywny kontekst przedstawionych rozwiązań pozwala zauważyć, iż dyspozycja art. 50 ust. 1 u.f.p. wiąże Radę Ministrów zarówno w odniesieniu do projektów ustaw, jak i rozporządzeń, zatem przepis ten ma szerszy zakres przedmiotowy niż postanowienia przywołanych wyżej ustępów 1a-1c odnoszące się wyłącznie do projektów ustaw ${ }^{10}$.

Ponadto o ile koniecznością uwzględniania w treści projektów limitów wydatków w perspektywie 10-letniej objęto jedynie „,zmiany poziomu wydatków”, a zatem zarówno ich zwiększenie, jak i zmniejszanie, o tyle w myśl art. 50 ust. 1 u.f.p. oceną przewidywanych skutków finansowych objęto projekty zmian legi-

${ }^{9}$ Również wejście w życie przepisów wykonawczych nie może powodować zmiany limitu wydatków jednostek sektora finansów publicznych określonego w ustawie, na podstawie której wydawane są przepisy wykonawcze, zaś wdrożenie wskazanych mechanizmów korygujących musi podlegać monitorowaniu przez określony w projekcie ustawy organ.

${ }^{10}$ Zob. też [Wyrok TK z dnia 20 lipca 2006 r. ..., Orzecznictwo Trybunału Konstytucyjnego...]. 
slacyjnych powodujących zwiększenie wydatków lub zmniejszenie dochodów jednostek sektora finansów publicznych [Lipiec-Warzecha 2011, s. 257]. Biorąc pod uwagę wskazane różnice oraz bezwzględnie obowiązujący charakter analizowanych przepisów, można uznać, że procedura limitowania wydatków, o której mowa w art. 50 ust. 1a-1c, 4, 5 i 7 u.f.p. stanowi rodzaj postępowania kwalifikowanego w stosunku do procedury określania skutków finansowych w przypadku projektów zmian legislacyjnych przewidujących jedynie zwiększenie wydatków.

W przypadku wprowadzenia stanu nadzwyczajnego ustawodawca wyłącza tylko wymóg stosowania procedury kwotowego limitowania wydatków oraz wdrażania mechanizmów korygujących, pozostawiając w mocy wymóg oceny skutków społeczno-gospodarczych wraz z koniecznością wskazywania źródeł pokrycia. Można zatem zgodzić się z wyrażonym w literaturze poglądem, że w przypadku zaistnienia okoliczności uzasadniających niestosowanie wskazanych wyżej rozwiązań dochodzi jedynie do rozluźnienia budżetowych rygorów dyscyplinujących, nie zaś do ich całkowitego wyłączenia [Lipiec-Warzecha 2011, s. 259].

Kolejnym rozwiązaniem ustawy o finansach publicznych stosowanym w przypadku wprowadzenia jednego ze stanów nadzwyczajnych na terytorium całego kraju jest wyłączenie na mocy art. 112d tej ustawy unormowań kształtujących tzw. tymczasową wydatkową regułę dyscyplinującą [Marchewka-Bartkowiak 2010]. Ogranicza ona tempo wzrostu tzw. wydatków elastycznych (o charakterze uznaniowym) oraz nowych wydatków sztywnych (prawnie zdeterminowanych [Russell 2010]) do 1\% realnie w skali roku w okresie obowiązywania procedury nadmiernego deficytu nałożonej na Polskę przez Radę Unii Europejskiej [Uzasadnienie projektu ustawy z dnia 26 lipca 2013 r. ...]. W praktyce wskazaną regułą dyscyplinującą objęto do końca 2012 r. ${ }^{11}$ przede wszystkim wydatki na wynagrodzenia i ich pochodne, a także wydatki bieżące oraz majątkowe jednostek sektora finansów publicznych [Uzasadnienie rządowego projektu ustawy...], co stanowiło zaledwie około 20\% wydatków budżetowych [Budzyński 2010, s. 8]. Stało się tak z uwagi na wyłączenie spod obowiązywania reguły m.in. wydatków na obsługę długu publicznego, należności na rzecz budżetu Unii Europejskiej i innych organizacji międzynarodowych oraz wydatków związanych z realizacją programów finansowanych z udziałem środków wspólnotowych, a także innych bezzwrotnych środków pochodzących ze źródeł zagranicznych (art. 112a ust. 2 u.f.p.).

Objęcie powyżej wskazanych wydatków regułą dyscyplinującą - limitującą ich wzrost do jednego punktu procentowego powyżej poziomu inflacji - spowodowałoby naruszenie przez Polskę zobowiązań o charakterze międzynarodowym oraz praw nabytych przez obywateli, podważając wiarygodność władz publicznych

\footnotetext{
${ }^{11}$ Stosowanie rozwiązań dotyczących tymczasowej reguły wydatkowej uregulowanych w art. $112 \mathrm{a}-112 \mathrm{~b}$ zostało zawieszone w okresie od 1 stycznia do 31 grudnia 2013 r. na mocy Ustawy z dnia 26 lipca 2013 r. o zmianie ustawy o finansach publicznych.
} 
[Lipiec-Warzecha 2011, s. 625]. Zasadność tej argumentacji nie zmienia faktu, że wyłączenie dyscyplinującej reguły wydatkowej w stosunku do znaczącej częśsi wydatków w istotny sposób utrudnia osiągnięcie celów wprowadzenia do ustawy tej reguły. Z drugiej jednak strony zawieszenie obowiązywania tymczasowej reguły wydatkowej w okresie od 1 stycznia do 31 grudnia 2013 r. ze względu na „powodowanie przez ten mechanizm utrudnień w przeciwdziałaniu dalszemu pogłębianiu się spowolnienia gospodarczego" [Uzasadnienie projektu ustawy z dnia 26 lipca 2013 r. ...] może świadczyć o ekonomicznej nieracjonalności określania celów zastosowania reguł wydatkowych w sposób bezwzględny.

Rozważając zagadnienie funkcjonowania finansów publicznych w okresie stanu nadzwyczajnego, należy przede wszystkim podkreślić, że wyłączenie przepisów kształtujących analizowaną wydatkową regułę dyscyplinującą przy jednoczesnym nieobowiązywaniu w tym okresie procedur sanacyjnych w szybkim tempie doprowadzić może do przekroczenia konstytucyjnie określonego progu zadłużenia państwa. Uzasadniając mocnym argumentem nadrzędności obowiązku ochrony życia i zdrowia ludzkiego względem mogącej powodować delikt konstytucyjny całkowitej swobody kształtowania wysokości pożyczkowych potrzeb budżetu państwa, można się również posunąć o krok dalej, wprowadzając w trakcie stanu nadzwyczajnego regułę wydatkową prowadzącą do ograniczania wydatków zdeterminowanych umowami międzynarodowymi. Warto również zwrócić uwagę na fakt, że wprowadzenie stanu nadzwyczajnego w okresie objęcia Polski zaleceniami Rady Unii Europejskiej dotyczącymi redukcji nadmiernego deficytu budżetowego (na podstawie art. 126 ust. 7 Traktatu o funkcjonowaniu Unii Europejskiej) skutkowałoby ex lege wyłączeniem określonego w art. 112 b u.f.p. wymogu uwzględniania omówionej wyżej reguły dyscyplinującej w procesie planowania ustawy budżetowej oraz opracowywania wieloletniego planu finansowego państwa. Wprowadzenie stanu nadzwyczajnego w tym okresie umożliwiłoby również przyjmowanie przez Radę Ministrów projektów ustaw określających zwolnienia, ulgi i obniżki, których skutkiem finansowym może być zmniejszenie dochodów jednostek sektora finansów publicznych w stosunku do wielkości wynikających z obowiązujących przepisów lub mogących powodować zwiększenie niektórych wydatków prawnie zdeterminowanych ${ }^{12}$. Wydaje się jednak, że realizacja ostatniej ze wskazanych opcji jest mało realistyczna. Podczas stanu nadzwyczajnego, zwłaszcza obowiązującego w okresie dłuższym niż 150 dni, można bowiem raczej spodziewać się redukowania wydatków związanych z obsługą zadłużenia niż ich intensyfikacji.

Zasada rozluźniania rygorów budżetowych w związku z wprowadzeniem stanu nadzwyczajnego znajduje swój wyraz również w wyłączeniu niektórych unor-

12 Katalog tych wydatków został wyczerpująco określony w art. 112a ust. 2 u.f.p., zaś wskazana możliwość kształtowania wydatków wynika z odczytania a contrario art. 113c tej ustawy. 
mowań kształtujących instytucję rezerw budżetowych. Najszerszy skutek prawny wiąże się z pominięciem - w wyniku wprowadzenia stanu nadzwyczajnego na terenie całego kraju lub jego części - ograniczenia, zgodnie z którym rezerwy celowe mogą być przeznaczone wyłącznie na cel, na jaki zostały utworzone, oraz wykorzystywane tylko zgodnie z klasyfikacją wydatków (art. 154 ust. 7 u.f.p.). Rezygnacja z tego ograniczenia daje możliwość przeznaczania środków rezerw celowych na realizację zadań wynikających z przepisów dotyczących wprowadzenia stanów nadzwyczajnych, zaś zmiana przeznaczenia rezerwy celowej nie wymaga zgody sejmowej komisji budżetowej. Obligatoryjnemu zawieszeniu podlegają również regulacje dotyczące niektórych terminów podziału rezerw. Co do zasady, podziału rezerw celowych dokonuje minister finansów nie później niż do dnia 15 października. Podlegający zawieszeniu w okresie obowiązywania stanu nadzwyczajnego wyjątek w tym zakresie polega na wydłużeniu do dnia 20 grudnia terminu podziału rezerwy celowej na finansowanie zadań, dla których udzielone zostały zapewnienia finansowania lub dofinansowania z budżetu państwa (art. 154 ust. 3 u.f.p.). Obowiązek niestosowania tego ograniczenia czasowego w trakcie stanu nadzwyczajnego oznacza, że wskazana rezerwa celowa będzie mogła być rozwiązana w terminie do 31 grudnia. Jak można wnioskować z brzmienia art. 154 ust. 2 u.f.p. a contrario, na skutek niezastosowania tego przepisu w przypadku wprowadzenia stanu nadzwyczajnego minister finansów zostanie również zwolniony z wymogu podjęcia decyzji co do podziału wskazanej rezerwy celowej. Jego kompetencje w zakresie rozwiązania analizowanej rezerwy celowej uzyskają charakter uznaniowy. W przypadku realizacji zadań wynikających z przepisów dotyczących wprowadzenia stanu nadzwyczajnego uchyleniu ulegnie także ograniczenie kompetencyjne wynikające z art. 154 ust. 6 u.f.p. Ograniczenie to uzależnia dokonanie przez ministra finansów podziału rezerwy celowej przeznaczonej na realizację programów finansowanych z udziałem środków pochodzących z Europejskiego Funduszu Rybackiego i na wspólną politykę rolną od konieczności złożenia wniosku przez ministrów właściwych do spraw rybołówstwa, rozwoju wsi i rynków rolnych. Wprowadzenie stanu nadzwyczajnego umożliwi zatem dokonanie podziału wskazanej rezerwy przez ministra finansów bez konieczności wniesienia tych wniosków.

Wprowadzenie stanu nadzwyczajnego prowadzi również do obligatoryjnej rezygnacji z ograniczeń o charakterze ilościowym $w$ zakresie procedury rozwiązywania rezerw. Zgodnie z art. 155 ust. 3 u.f.p. rezerwa ogólna nie może być przeznaczona na zwiększenie wydatków, które zostały zmniejszone w trybie prawidłowo dokonanych przeniesień. Jak można wnioskować z treści art. 171 u.f.p. regulującego zasady dokonywania przeniesień, w analizowanej normie chodzi o przeniesienia między rozdziałami a paragrafami w ramach danej części budżetu państwa. Zawieszenie tej normy sprawi, że organy uprawnione do dyspo- 
nowania rezerwą ogólną będą mogły wykorzystać środki pochodzące z rezerwy ogólnej jako źródło pokrycia wydatków uprzednio ograniczonych. Dodatkowe osłabienie rygorów związanych z wykonywaniem ustawy budżetowej przewiduje art. 180 u.f.p., który umożliwia dokonywanie przeniesienia wydatków budżetowych między częściami a działami budżetu. Rozwiązanie takie sprawia, że przeniesienie wydatków - wbrew utrwalonej w doktrynie prawa finansowego jej funkcji $1^{13}$ - pozwala władzy wykonawczej na dokonywanie przesunięć środków budżetowych wymagających co do zasady zgody parlamentu.

\section{Wnioski}

Problematyka prawnofinansowych skutków wprowadzenia stanów nadzwyczajnych nie została dotąd szerzej zbadana w doktrynie nauk prawnych. Brakuje w tym zakresie zarówno opracowań o charakterze monograficznym, jak i szerszych ujęć w formie komentarzy. Przyczyn naukowej wstrzemięźliwości można upatrywać w hipotetycznym charakterze tych sytuacji prawnych. W połączeniu z nieprzewidywalnością przyczyn wprowadzenia stanu nadzwyczajnego i rozszerzonymi możliwościami prawodawczymi organów wykonawczych powstaje pole badawcze umożliwiające snucie refleksji w części empirycznie niesprawdzalnych. Jest to jednak pole bardzo szerokie, obejmujące również grupę problemów nośnych społecznie, takich jak polityczny kontekst oceny przesłanek wprowadzenia stanu klęski żywiołowej, ewentualny wpływ ogłoszenia stanu klęski żywiołowej na gospodarkę finansową jednostek samorządu terytorialnego oraz prawnofinansową pozycję poszczególnych jednostek życia społecznego. Analiza dokonywana zarówno z perspektywy funkcjonowania związków publiczno-prawnych, jak i zastosowania instytucji służących bezpośrednio obywatelom, może również stanowić metodę badania rozwiązań funkcjonujących w prawie Unii Europejskiej, a dotyczących pomocy państwom dotkniętym aktami terroru, skutkami katastrof naturalnych i pandemii. Problemy te wymagają odrębnego zbadania.

De lege ferenda, z uwagi na brak logicznej zgodności między obligatoryjnością wyłączenia w sytuacji stanu nadzwyczajnego niektórych regulacji ustawy o finansach publicznych - w szczególności dotyczących procedur sanacyjnych oraz reguł wydatkowych chroniących budżet przed nadmiernym zadłużeniem - a niemożliwością dokonania w czasie trwania stanu nadzwyczajnego zmiany określonego w art. 216 ust. 5 Konstytucji limitu zadłużenia państwa wydaje się, iż należy rozważyć zmianę treści tego przepisu Konstytucji w taki sposób, aby nie doprowadził on w przyszłości do paraliżu decyzyjnego w przypadku uzasadnionej

${ }^{13}$ Mającej służyć jedynie dokonywaniu niewielkich korekt w strukturze wydatków budżetowych, nie zaś wprowadzaniu zmian o charakterze fundamentalnym. 
społecznie lub ekonomicznie konieczności jego naruszenia właśnie w czasie trwania stanu nadzwyczajnego. Zmiana treści mogłaby polegać na dodaniu w art. 216 ust. 5 Konstytucji trzeciego zdania o treści: „Przepisu tego nie stosuje się w przypadku wprowadzenia na całym terytorium Rzeczypospolitej Polskiej stanu wojennego, stanu wyjątkowego lub stanu klęski żywiołowej”.

\section{Literatura}

Banaszak B. [2012], Konstytucja Rzeczypospolitej Polskiej. Komentarz, C.H. Beck, Warszawa.

Bryk T. [2011], Przeglad regulacji stanów nadzwyczajnych w przepisach Konstytucji RP, „Przegląd Prawa Konstytucyjnego”, nr 1 (5).

Budzyński T. [2010], Opinia o ustawie o zmianie ustawy o finansach publicznych oraz niektórych innych ustaw (druk senacki $\mathrm{nr}$ 1062), http://ww2.senat.pl/k7/dok/opinia/2010/oe-159.pdf (dostęp: 30.10.2013).

Kosikowski C. [2011], Ustawa o finansach publicznych. Komentarz, LexisNexis, Warszawa.

Kosikowski C., Szpringer Z. [2000], Finanse publiczne. Komentarz do ustawy z dnia 26 listopada 1998 r., Zachodnie Centrum Organizacji, Zielona Góra.

Lipiec-Warzecha L. [2011], Ustawa o finansach publicznych. Komentarz, ABC a Wolters Kluwer Business, Warszawa.

Marchewka-Bartkowiak K. [2010], Reguły fiskalne, ,Analizy BAS”, nr 7.

Mażewski L. [2009], Kilka uwag o instytucji stanu nadzwyczajnego, „Wojskowy Przegląd Prawniczy", nr 2.

Polarczyk K. [2005], Ekspertyza w sprawie zasadności przepisu art. 69 ust.1 i art. 79 ust. 1, który powiększa państwowy dług publiczny o kwotę przewidywanych wypłat $z$ tytułu poręczeń i gwarancji udzielonych przez jednostki sektora finansów publicznych, jeżeli wydatki na ten cel sa ujęte w ustawie budżetowej w częściach 78 i 79, http://www.sejm.gov.pl (dostęp: 30.10.2013).

Prokop K. [2005], Stany nadzwyczajne w Konstytucji Rzeczypospolitej Polskiej, Temida 2, Białystok.

Russel P. [2010], Wydatki budżetowe w Polsce [w:] Polityka budżetowa, red. G. Gołębiowski, ,Studia BAS”, nr 3.

Sobczyński D. [2003], Procedury ostrożnościowe i sanacyjne w ustawie o finansach publicznych, „Glosa”, $\mathrm{nr} 12$.

Ustawa o finansach publicznych. Komentarz [2012], red. P. Smoleń, C.H. Beck, Warszawa.

Uzasadnienie projektu ustawy z dnia 26 lipca 2013 r. o zmianie ustawy o finansach publicznych, druk sejmowy nr 1575, http://www.sejm.gov.pl (dostęp: 10.2013).

Uzasadnienie rządowego projektu ustawy o zmianie ustawy o finansach publicznych oraz niektórych innych ustaw, druk sejmowy nr 3576, http://www.sejm.gov.pl (dostęp: 30.10.2013).

Zubik M. [2001], Budżet państwa w polskim prawie konstytucyjnym, Wydawnictwo Sejmowe, Warszawa. 


\section{Akty normatywne}

Traktat o funkcjonowaniu Unii Europejskiej, Dz.Urz. UE, C115 z dnia 9 maja 2008 r.

Ustawa z dnia 27 sierpnia 1997 r. o rehabilitacji zawodowej i społecznej oraz zatrudnianiu osób niepełnosprawnych, Dz.U. z 2011 r., nr 127, poz. 721, z późn. zm.

Ustawa z dnia 18 kwietnia 2002 r. o stanie klęski żywiołowej, Dz.U., nr 62, poz. 558, z późn. zm.

Ustawa z dnia 21 czerwca 2002 r. o stanie wyjątkowym, Dz.U., nr 113, poz. 985, z późn. $\mathrm{zm}$.

Ustawa z dnia 29 sierpnia 2002 r. o stanie wojennym oraz o kompetencjach Naczelnego Dowódcy Sił Zbrojnych i zasadach jego podległości konstytucyjnym organom Rzeczypospolitej Polskiej, Dz.U., nr 156, poz. 1301, z późn. zm.

Ustawa z dnia 27 sierpnia 2009 r. o finansach publicznych, Dz.U. z 2013 r., poz. 885, z późn. zm.

Ustawa z dnia 16 grudnia 2010 r. o zmianie ustawy o finansach publicznych oraz niektórych innych ustaw, Dz.U., nr 257, poz. 1726.

Ustawa z dnia 26 lipca 2013 r. o zmianie ustawy o finansach publicznych, Dz.U. z 2013 r., poz. 938.

\section{Orzecznictwo}

Wyrok TK z dnia 20 lipca 2006 r., sygn. akt K 40/05.

Orzecznictwo Trybunału Konstytucyjnego. Zbiór urzędowy, Seria A 2006, nr 7, poz. 82, LEX nr 198677.

\section{The Legal-financial Consequences of Implementing a State of Emergency}

Acts regulating principles of operation of the state do not contain legal-financial norms during a state of emergency. The constitutional principle of the uniqueness of states of emergency leads one to believe, however, that the unusual nature of the situation in which a state and its citizens are in during a state of emergency justifies the taking of financial decisions legally that would in other circumstances be unacceptable. This thesis seems to be confirmed by the Public Finance Act, which provides for the exemption, at the time a state of emergency is introduced, of certain regulations concerning, among other things, the rigours associated with so-called disciplinary rule expenditure, the division of specific provisions and general provision and effecting transfers of budget expenditures, but above all of restrictions associated with implementing prudent and sanative procedures. The question therefore arises as to how far, in the purview of financial law, an executive branch, endowed with special powers during the state of emergency, can actually go without sacrificing its status as a legal democracy.

Keywords: state of emergency, sanative procedure, expense disciplining rule, budget reserves, transfer of expenses, fiscal discipline, procedure for excessive deficit. 